\title{
Redactioneel
}

\section{De rol van de toezichthouder in crisistijd}

\author{
Frans van Bruggen en Anna Merz*
}

We leven in gekke tijden - dat horen we de laatste tijd (helaas) vaak genoeg. De uitbraak van het coronavirus heeft ons leven drastisch veranderd, zowel zakelijk als privé, en doet een beroep op het incasseringsvermogen van burgers en de samenleving. Nooit eerder werden we in onze moderne geglobaliseerde tijden op deze schaal geconfronteerd met een voorlopig oncontroleerbaar fenomeen. De nieuwe situatie levert onrust, onzekerheid en soms stress op; ze legt immers de illusie van de menselijke beheersbaarheid van de wereld maar ook van de valkuilen van het neoliberale systeem bloot. We zijn en blijven kwetsbaar als mensen. Maar niet alleen de kwetsbaarheid van individuele burgers wordt aangetast, ook de samenleving als geheel heeft flinke schokken te verwerken. De economie is piepend en krakend tot stilstand gekomen, de gezondheidszorg staat onder hoogspanning en basale vrijheden worden ingeperkt.

De crisis vraagt veel, van iedereen. Wie kan, werkt thuis en vergadert online (terwijl men tegelijkertijd de kinderen vermaakt en verzorgt). Bezoeken aan ouderen in verpleeghuizen zijn voorlopig niet mogelijk en de anderhalvemetersamenleving begint langzaam 'het nieuwe normaal' te worden. Vaak genoeg horen we dat we het virus alleen met z'n allen kunnen beheersen. Hierop is ook de centrale communicatiestrategie en campagne van de Rijksoverheid gebaseerd: 'Alleen samen'. Daarbij hoort niet alleen de verantwoordelijkheid die ieder individu draagt maar ook de vraag naar solidariteit met en respect voor elkaar. Solidariteit met en respect voor de burgers die werkzaam zijn in cruciale beroepen, maar ook met de zieken, ouderen, werklozen en getroffen ondernemers. De crisis is dan ook een moment van kri-

* $\quad$ Drs. F.P. van Bruggen is buitenpromovendus en toezichthouder integere bedrijfsvoering bij de NZa en redactielid van Tijdschrift voor Toezicht. A. Merz (MA) is promovenda bij de sectie Criminologie van de Erasmus Universiteit Rotterdam en redactielid van Tijdschrift voor Toezicht. tische reflectie op onze fundamentele normen en waarden. Waar staan we voor als Nederlanders? Hoe gaan we ermee om dat onze vrijheid wordt ingeperkt voor een hoger doel, namelijk solidariteit en de volksgezondheid? Net zoals in eerdere crisissituaties hechten mensen waarde aan een overheid, die als betrouwbare, solide en voorspelbare crisisbeheerser optreedt. Heldere en consistente communicatie lijkt een cruciale rol te spelen in crisissituaties; ${ }^{1}$ bij de rijksoverheid, bij bedrijven en brancheorganisaties, maar zeker ook bij toezichthouders. In deze uitzonderlijke situatie kijken we gespannen en hoopvol naar de overheid en haar reactie; naar de wekelijkse persconferenties en cijfers en adviezen van het Rijksinstituut voor Volksgezondheid en Milieu (RIVM) en de Gemeentelijke Gezondheidsdienst (GGD). Er is veel aandacht voor de manier van communiceren. Mensen hebben behoefte aan duidelijke, toegankelijke en laagdrempelige informatie. Dat communicatie niet altijd soepel verloopt, hebben we eerder ook bij de Nederlandse overheid gezien. ${ }^{2}$ En toch blijft het cruciaal. Communicatie, toelichting en transparantie zijn immers onderdelen van een open democratie, ook in crisistijden, zei bondskanselier Angela Merkel toen ze Duitsland op 18 maart toesprak in een nationale tvtoespraak. $^{3}$

Ook toezichthouders hebben in deze coronacrisis met uitdagingen te maken. Ze bevinden zich opeens in een situatie waarin de procedures en praktijken van het 'oude normaal' niet meer vanzelfsprekend werken. Concreet zijn er twee uitdagingen waarmee toezichthouders zich geconfronteerd zien. Beide uitdagingen vragen om gepaste en duidelijke communicatie. Allereerst kan de publieke waarde waar een toezichthouder voor staat een

1. Instituut Fysieke Veiligheid, Handboek Communicatie in Crisissituaties, 2004.

2. 'Opnieuw kritiek op het kabinet in coronadebat', Trouw 26 maart 2020.

3. www.bundesregierung.de/resource/blob/975232/1732182/

d4af29ba76f62f61f1320c32d39a7383/fernsehansprache-vonbundeskanzlerin-angela-merkel-data.pdf?download=1. 
andere positie innemen in het collectief-maatschappelijke waardensysteem. ${ }^{4}$ In principe heeft elke toezichthouder bepaalde kernwaarden die centraal staan in zijn toezicht. Waar de Nederlandse Zorgautoriteit (NZa) staat voor betaalbare en toegankelijke gezondheidszorg, ${ }^{5}$ staat de Autoriteit Persoonsgegevens (AP) voor privacy, ${ }^{6}$ de Nederlandse Voedsel- en Warenautoriteit (NVWA) voor voedselveiligheid, dierenwelzijn en milieu ${ }^{7}$ en De Nederlandsche Bank (DNB) voor financiële stabiliteit. Hoewel deze waarden redelijk abstract aanvoelen, zijn ze wel degelijk de bron van de normen waarop (on)wenselijk gedrag wordt gebaseerd. Ze vormen het startpunt van het toezicht en vormen de bron van zijn legitimiteit en bestaansrecht. Maar wat als een crisis onze maatschappelijke waardenhiërarchie herschikt? Concreet uit zich dit bijvoorbeeld in de discussie rondom de waarden privacy en gezondheid; verschillende Corona-apps zouden het mogelijk maken de volksgezondheid te tracken ${ }^{8}$ maar tasten daarmee wel onze privacy aan. ${ }^{9}$ Over het algemeen zien we, zeker op de korte termijn, een heroriëntering op collectieve waarden zoals gezondheid, solidariteit en socialiteit ten laste van individuele en economische waarden. Deze dynamiek in onze collectieve waardenstelsels is iets wat een crisis kenmerkt. Toezichthouders moeten dus oog hebben voor deze dynamiek en zich bezinnen op het relatieve belang van hun kernwaarden in crisistijden. Het is belangrijk dat een toezichthouder zich een juiste communicatiestrategie aanmeet die recht doet aan dit relatieve belang. Voor zelfprofilering is een crisistijd ongeschikt.

De tweede uitdaging voor toezichthouders centreert zich rond een dilemma ten aanzien van hun reguliere toezicht- en handhavingswerkzaamheden. Verschillende toezichthouders hebben aangegeven hun toezicht te zullen verlichten tijdens de crisis, om hun onder toezicht gestelden tegemoet te komen. Zo verlichtte DNB de buffereisen, ${ }^{10}$ stopte de Inspectie Gezondheidszorg en Jeugd (IGJ) met de reguliere inspecties, ${ }^{11}$ verruimde de Autoriteit Consument \& Markt (ACM) concurrentieregels $^{12}$ en schortte de Autoriteit Financiële Markten (AFM) grote gegevensuitvragen op. ${ }^{13}$ Deze maatregelen zijn noodzakelijk, wordt gesteld, om onder toezicht gestelde organisaties niet onnodig te belasten in deze

4. In de sociale wetenschappen en filosofie wordt een waardensysteem gepresenteerd als een hiërarchisch systeem van waarden dat iemand zijn handelingen stuurt. Zie: N. Rescher, Introduction to value theory, Oxford Handbooks, Englewood Cliffs, NJ: Prentice-Hall 1969.

5. Nederlandse Zorgautoriteit, Strategische agenda 2018-2020.

6. Autoriteit Persoonsgegevens, Focus AP 2020-2023. Dataprotectie in een digitale samenleving.

7. Nederlandse Voedsel-en Warenautoriteit, Jaarplan 2020 NVWA

8. 'Zo werkt de corona-app die op symptomen controleert', RTLNieuws 9 april 2020.

9. Autoriteit Persoonsgegevens, 'AP: privacy corona-apps niet aangetoond', nieuwsbericht 20 april 2020.

10. 'DNB verlicht buffereisen banken vanwege coronacrisis', NRC 17 maart 2020.

11. 'IGJ stopt alle reguliere inspecties', Skipr nieuwsbericht 31 maart 2020.

12. 'ACM verruimt concurrentieregels door corona', Retailnews 19 maart 2020.

13. Autoriteit Financiële Markten, 'AFM schort uitvragen deels op tot 1 juni', nieuwsbericht 26 maart 2020. onzekere tijd. Er is echter ook een keerzijde. Waar grotendeels het goede in de mens naar boven komt in crisistijden, lijken er ook partijen te zijn die de kans aangrijpen en onwenselijk of illegaal gedrag vertonen, wellicht in de vooronderstelling dat de toezichthouder toch niet zal ingrijpen. ${ }^{14}$ Zo stelde de Kansspelautoriteit (Ksa) dat illegale goksites proberen te profiteren van de crisis, ${ }^{15}$ waarschuwde de AFM voor oplichters ${ }^{16}$ en arresteerde de Fiscale inlichtingen- en opsporingsdienst (FIOD) twee mannen voor oplichting met mondkapjes. ${ }^{17}$ In de crisis moeten toezichthouders dus zowel flexibel zijn om hun onder toezicht staande instellingen niet te overbelasten, als ook oog houden op de randvoorwaarden van hun toezichtsdomein door waar nodig te handhaven. Een toezichthouder moet zowel faciliteren als corrigeren. Ook hierbij is de communicatiestrategie voor toezichthouders cruciaal. Hoe verenig je een faciliterende en een waarschuwende boodschap in je communicatie naar je toezichtsdomein? En hoe krijg je draagvlak als je als toezichthouder besluit te handhaven?

De beslissingen rondom het coronavirus leren ons opnieuw dat (nieuwe) maatregelen altijd om een balans tussen monitoring en goede communicatie vragen, maar uiteindelijk ook om een verandering van sociale normen. Inzicht geven in het relatieve belang van het toezicht en duidelijkheid over (on)wenselijk gedrag in deze (tijdelijke) omstandigheden zijn van doorslaggevend belang. Op die manier kan een toezichthouder de randvoorwaarden van zijn toezichtsdomein borgen.

Het aspect van communicatie en de veronderstelde problematiek voor toezichthouders komt ook in een aantal bijdragen in dit nummer aan bod.

In het artikel over overtredingen van het Besluit risico's zware ongevallen (Brzo) bij chemische bedrijven gaan Ellen Wiering, Marieke Kluin, Marlijn Peeters, Arjan Blokland en Wim Huisman in op de mate en aard van regels die worden overtreden om zo patronen en een mogelijke specialisatie te identificeren. Zijn brzo-overtreders specialisten of generalisten? Hun analyse laat zien dat de meeste brzo-overtreders het tweede zijn (generalisten); voor toezichthouders zou dat meer aandacht voor de algemene oorzaken van overtredingen betekenen. Het artikel van Margot Aelen en Hugo Prince biedt een interessant inkijkje in de, voor veel van ons nog steeds verbazingwekkende, wereld van cryptocurrency en de uitdagingen hiervan voor het (integriteits)toezicht door DNB. Zij reflecteren op de uitdagingen rondom het implementeren van een nieuwe maatregel en wat de uitbreiding in taak voor het toezicht van DNB betekent. Frans van Bruggen en Foep Beckers gaan in hun bijdrage 'Nut en noodzaak van toezicht op artificiële intelligentie' in op de vraag hoe toezicht op artifici-

14. 'Crisismaatregelen gaan gepaard met hoger frauderisico', opinie, Het Financieele Dagblad 5 april 2020.

15. 'Toezichthouder: illegale goksites proberen te profiteren van coronavirus', www.nu.nl 18 maart 2020.

16. 'Toezichthouder AFM waarschuwt voor oplichters in crisistijd', www.iex.nl 9 april 2020.

17. 'FIOD pakt twee mannen op voor oplichting met mondkapjes', nieuwsbericht RTLnieuws 6 april 2020. 
ele intelligentie (AI) er uit zou moeten komen te zien. Communicatie van de toezichthouder naar zijn toezichtsdomein is hier een belangrijk onderdeel van; de toezichthouder moet immers duidelijk aangeven hoe toezichtssubjecten kunnen voldoen aan de wensen van de toezichthouder op dit onontgonnen terrein. In hun bijdrage over metatoezicht van de Inspectie Justitie en Veiligheid (Inspectie JenV) op de politie concluderen Ira Helsloot en Peter van Lochem dat gebrek aan communicatie tussen toezichthouder en de onder toezicht gestelde juist belemmerd kan werken. Aan de hand van de zaak Hümeyra laten Helsloot en Van Lochem een aantal valkuilen van samenwerking zien.

'Kan een franchiseorganisatie in de zorg, die zelf geen zorg verleent, verantwoordelijk worden gehouden voor de kwaliteit van zorg bij de franchisenemer?' De Notenkrater van $\mathcal{F}$ os Boertjens in dit nummer reflecteert op de uitspraak van de Afdeling bestuursrechtspraak van de Raad van State met betrekking tot deze vraag. Uiteindelijk stipt Boertjens een brede discussie over het begrip 'medeplegers' aan. In de column schrijft Muel Kaptein over de ware aard van toezichthouders in crisistijd en hoe deze zich uit in de relatie tussen toezichthouder en onder toezicht gestelde aan de hand van het spreekwoord: In nood leert men zijn vrienden kennen. De opiniebijdrage van Arnt Mein reageert op de oproep door de AFM en DNB om feedback te geven op de conceptversie van het geactualiseerde handhavingsbeleid. Hoewel de uitkomst van de consultatie nog niet bekend is, ziet Mein een gemiste kans in het toch onvoldoende vernieuwde karakter van het 'richtinggevend beleid voor het bepalen van de inzet van handhavingsinstrumenten'. En tot slot onderzoeken Marcel Pfeiffer en Femke de Vries in hun twee opiniebijdragen de vraag hoe het met het toezicht op de accountancysector staat. Hoewel ze qua insteek verschillen, kunnen hun bijdragen als op elkaar voortbouwend verhalen worden gelezen. Dat de vele rapporten en toezichtinitiatieven rondom deze sector niet hebben geleid tot andere uitkomsten laat zien dat er nog geen optimale communicatiestrategie is gekozen om deze sector daadwerkelijk te laten veranderen. 